\title{
CORRECTION
}

\section{Correction to: Comparison of several models for fitting breakthrough curves of radionuclides transport in crushed rock: ground water systems}

\author{
Štefan Palágyi ${ }^{1}$ (]) \\ Published online: 30 September 2019 \\ (c) Akadémiai Kiadó, Budapest, Hungary 2019

\section{Correction to: \\ Journal of Radioanalytical and Nuclear Chemistry (2019) 321:1067-1071 \\ https://doi.org/10.1007/s10967-019-06651-1}

In the original publication of the article, Table 1 was published incorrectly. The correct version of Table 1 is given in this correction.

The original article can be found online at https://doi.org/10.1007/ s10967-019-06651-1.

Štefan Palágyi

istvan.palagyi@email.cz

1 Department of Nuclear Chemistry, Faculty of Nuclear

Sciences and Physical Engineering, Czech Technical

University in Prague, 11519 Prague, Czech Republic 
Table 1 Parameters for calculation of breakthrough curves in respective models for ${ }^{137} \mathrm{Cs}^{+}$transport in granite columns of $0.125-0.63 \mathrm{~mm}$ grain size

\begin{tabular}{|c|c|c|c|c|c|c|}
\hline Parameter & Clark & Thomas & MDR & Yan & Yon-Nelson & $\begin{array}{l}\text { Palágyi- } \\
\text { Štamberg }\end{array}$ \\
\hline$A$ & 10 & & & & & \\
\hline$r$ & 0.1 & & & & & \\
\hline$n$ & 1.01 & & & & & \\
\hline$k_{\mathrm{Th}}$ & & 0.05 & & & & \\
\hline$q_{0}$ & & 8 & 10 & & & \\
\hline$M$ & & 1 & 8.15 & & & \\
\hline$Q$ & & 0.1 & & 0.25 & & \\
\hline$a_{\mathrm{MDR}}$ & & & 6 & & & \\
\hline$b$ & & & & 20 & & \\
\hline$a$ & & & & 10 & & \\
\hline$k_{\mathrm{YN}}$ & & & & & 0.1 & \\
\hline$\tau$ & & & & & 81.6 & \\
\hline$n_{\mathrm{PV}}$ & 83.4 & 79.9 & 81.9 & 79.2 & 81.5 & 80.0 \\
\hline$R_{\text {mod }}$ & 83.4 & 79.9 & 81.9 & 79.2 & 81.5 & 80.0 \\
\hline$P e$ & & & & & & 25 \\
\hline$\varepsilon(\%)$ & 4.0 & 0.4 & 2.1 & 1.2 & 1.6 & 0.2 \\
\hline
\end{tabular}

Publisher's Note Springer Nature remains neutral with regard to jurisdictional claims in published maps and institutional affiliations. 